\title{
CTC1 Gene
}

National Cancer Institute

\section{Source}

National Cancer Institute. CTC1 Gene. NCI Thesaurus. Code C152098.

This gene plays a role in telomere replication. 